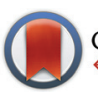

CrossMark \& click for updates

Cite this: Dalton Trans., 2016, 45 8428

Received 10th March 2016,

Accepted 8th April 2016

DOI: $10.1039 / c 6 d t 00958 a$

www.rsc.org/dalton

\section{Does $\left[\mathrm{TcF}(\mathrm{CO})_{5}\right]$ exist? The crystal and molecular structure of $\left[\mathrm{Tc}(\mathrm{CO})_{3}(\mathrm{OH})_{0.49} \mathrm{~F}_{0.51}\right]_{4} \cdot\left[\mathrm{Tc}(\mathrm{CO})_{5}\left(\mathrm{BF}_{4}\right)\right] \dagger$}

\author{
E. S. Stepanova, ${ }^{a}$ V. V. Gurzhiy, ${ }^{b}$ M. Yu. Tyupina, ${ }^{a}$ A. E. Miroslavov, ${ }^{\text {ta }}$ G. V. Sidorenko ${ }^{a}$ \\ and A. A. Lumpov ${ }^{a}$
}

Technetium pentacarbonyl fluoride $\left[\mathrm{TCF}(\mathrm{CO})_{5}\right]$ was prepared for the first time by reaction of $\left[\mathrm{Tcl}(\mathrm{CO})_{5}\right]$ with solid $\mathrm{AgF}$ in a dichloromethane solution at $-23^{\circ} \mathrm{C}$. Low temperature crystallization of the resulting compound in a glass vial yielded an unusual complex $\left[\mathrm{Tc}(\mathrm{CO})_{3}(\mathrm{OH})_{0.49} \mathrm{~F}_{0.51}\right]_{4} \cdot\left[\mathrm{Tc}(\mathrm{CO})_{5}\left(\mathrm{BF}_{4}\right)\right]$ characterized by single crystal XRD.

\section{Introduction for $\left[\mathrm{Tc}(\mathrm{CO})_{3}(\mathrm{OH})_{0.49} \mathrm{~F}_{0.51}\right]_{4} \cdot\left[\mathrm{Tc}(\mathrm{CO})_{5}\left(\mathrm{BF}_{4}\right)\right](1)$}

Technetium is an artificial radioactive element occupying the central position in the d metal block. The study of its chemistry is substantially restricted by its radioactivity and difficult availability. At the same time, the data on its chemical behavior are necessary for a comprehensive understanding of the chemistry of $d$ elements. The question of whether the carbonyl complexes known for manganese and rhenium can be prepared likewise for technetium remains open to date for a number of carbonyl species. In particular, no data on $[\mathrm{TcF}$ $\left.(\mathrm{CO})_{5}\right]$ are available, whereas its analog $\left[\operatorname{ReF}(\mathrm{CO})_{5}\right]^{1,2}$ has been prepared but not structurally characterized many years ago. Previously we found that the fluoride ion, unlike chloride, bromide and iodide ions, exhibits very weak affinity for monovalent technetium. ${ }^{3}$ In addition, we also attempted the preparation of $\left[\mathrm{TcF}(\mathrm{CO})_{5}\right]$ by carbonylation of potassium pertechnetate with carbon monoxide in aqueous hydrofluoric acid. In this case, tetrameric $\left[\mathrm{Tc}_{4}(\mathrm{CO})_{12} \mathrm{~F}(\mathrm{OH})_{3}\right]$ rather than the target monomer was obtained. ${ }^{4}$ It should be noted that the same procedure performed with $\mathrm{HX}(\mathrm{X}=\mathrm{Cl}, \mathrm{Br}, \mathrm{I})$ gives the corresponding pentacarbonyl halides $\left[\mathrm{TcX}(\mathrm{CO})_{5}\right]^{5}$ in a reasonable yield, i.e., the hydroxide anion strongly competes with the fluoride anion for coordination to technetium(I) even in an acid medium. These data suggest that the preparation of $\left[\mathrm{TcF}(\mathrm{CO})_{5}\right]$ should be attempted under rigorously anhydrous conditions. It

\footnotetext{
${ }^{a}$ Khlopin Radium Institute, 2-i Murinskii pr. 28, St. Petersburg, 194021 Russia. E-mail: amiroslav@mail.ru

${ }^{b}$ Department of Crystallography, St. Petersburg State University, University emb. 7/9, St. Petersburg, 199034 Russia

$\dagger$ Electronic supplementary information (ESI) available: Unit cell and refinement parameters, selected bond lengths, selected bond angles in the structure $\mathbf{1}$ and IR spectrum. CCDC 1463843. For ESI and crystallographic data in CIF or other electronic format see DOI: 10.1039/c6dt00958a
}

should also be noted that technetium pentacarbonyl halides are unstable with respect to thermal decarbonylation, with the decarbonylation rate increasing in the order $\mathrm{I}<\mathrm{Br}<\mathrm{Cl}^{6}{ }^{6}$ Thus, $\left[\mathrm{TcF}(\mathrm{CO})_{5}\right]$, if it does exist, should readily undergo thermal decarbonylation to form, most likely, tricarbonyl derivatives. Another possible degradation pathway is a nucleophilic attack on the coordinated $\mathrm{CO}$ ligands. For example, this process is believed to be responsible for the rapid decomposition of the $\left[\mathrm{Tc}(\mathrm{CO})_{6}\right]^{+}$cation in aqueous solution upon alkalization. ${ }^{7}$ Taking into account the above facts, in this study we attempted the preparation of $\left[\mathrm{TcF}(\mathrm{CO})_{5}\right]$ by substitution of the iodide ion in $\left[\mathrm{TcI}(\mathrm{CO})_{5}\right]$ with a fluoride anion in nonaqueous solutions. In the course of these experiments, we obtained an unusual adduct $\left[\mathrm{Tc}(\mathrm{CO})_{3}(\mathrm{OH})_{0.49} \mathrm{~F}_{0.51}\right]_{4} \cdot\left[\mathrm{Tc}(\mathrm{CO})_{5}\left(\mathrm{BF}_{4}\right)\right]$ containing the pentacarbonyl and tetrameric tricarbonyl technetium complexes.

\section{Experimental}

Technetium pentacarbonyl iodide $\left[\mathrm{TcI}(\mathrm{CO})_{5}\right]$ was prepared as described previously ${ }^{5}$ by high-pressure carbonylation of potassium pertechnetate with formic acid in the presence of hydrogen iodide at $170{ }^{\circ} \mathrm{C}$. Silver fluoride was obtained by treatment of silver carbonate with concentrated hydrofluoric acid. ${ }^{8}$ Dark brown AgF was dried under reduced pressure at $100{ }^{\circ} \mathrm{C}$ for $2 \mathrm{~h}$. The product was identified by powder X-ray diffraction. Reflections with d 2.85, 2.47, and $1.746 \AA$ are similar to those of cubic AgF (no. 3-890 JCPDS). $\mathrm{AgBF}_{4}$ was purchased from Aldrich. The IR spectra of the samples in the form of dichloromethane solutions $\left(\mathrm{CaF}_{2}\right.$ windows) were recorded on a Shimadzu FTIR-8700 spectrometer. Dichloromethane was distilled from phosphorus pentoxide.

\section{Reaction of $\left[\mathrm{TcI}(\mathrm{CO})_{5}\right]$ with $\mathrm{AgF}$}

Preparation of $\left[\mathrm{Tc}(\mathrm{CO})_{3}(\mathrm{OH})_{0.49} \mathrm{~F}_{0.51}\right]_{4} \cdot\left[\mathrm{Tc}(\mathrm{CO})_{5}\left(\mathrm{BF}_{4}\right)\right]$ (1). All manipulations were performed in a dry glove box filled with 
argon. A weighed portion of $\left[\mathrm{TcI}(\mathrm{CO})_{5}\right](23.23 \mathrm{mg}, 0.063 \mathrm{mmol})$ was mixed with $\mathrm{AgF}(80.8 \mathrm{mg}, 0.64 \mathrm{mmol})$ in dry dichloromethane $(1 \mathrm{~mL})$ in a $10 \mathrm{ml}$-glass vial. The vial was sealed and placed in a frozen carbon tetrachloride bath. The reaction mixture was stirred on a magnetic stirrer at $-23{ }^{\circ} \mathrm{C}$ for $1 \mathrm{~h}$. Then the solution was filtered at room temperature. The filtrate was allowed to evaporate in a desiccator over concentrated sulfuric acid in the presence of paraffin shavings at $8{ }^{\circ} \mathrm{C}$. Colorless cubic crystals suitable for single crystal X-ray diffraction were formed on the walls of the vial in 2 weeks. The amount of the product was insufficient for obtaining analytical data and a satisfactory IR spectrum.

\section{Single crystal X-ray diffraction}

The prismatic crystal of $\mathbf{1}$ was mounted on a thin glass fiber for X-ray diffraction analysis, which was carried out using a Bruker KAPPA DUO diffractometer equipped with an APEX II CCD planar detector operated with microfocused monochromated $\mathrm{MoK}_{\alpha}$ radiation at $50 \mathrm{kV}$ and $0.6 \mathrm{~mA}$. More than a hemisphere of X-ray diffraction data $\left(\theta_{\max }=25.00^{\circ}\right)$ were collected at room temperature for the crystal with frame widths of $0.5^{\circ}$ in $\omega$ and exposure of $60 \mathrm{~s}$ spent per frame. Data were integrated and corrected for background, Lorentz, and polarization effects using an empirical spherical model by means of the Bruker programs APEX2 and XPREP. Absorption correction

Table 1 Unit cell and refinement parameters of 1

\begin{tabular}{|c|c|}
\hline Parameter & (1) \\
\hline Formula & {$\left[\mathrm{Tc}(\mathrm{CO})_{3}(\mathrm{OH})_{0.49} \mathrm{~F}_{0.51}\right]_{4} \cdot\left[\mathrm{Tc}(\mathrm{CO})_{5}\left(\mathrm{BF}_{4}\right)\right]$} \\
\hline Crystal system & Monoclinic \\
\hline$a(\AA)$ & $14.0520(15)$ \\
\hline$b(\AA)$ & $9.0526(10)$ \\
\hline$c(\AA)$ & $26.357(3)$ \\
\hline$\alpha\left({ }^{\circ}\right)$ & 90 \\
\hline$\beta\left(0^{\circ}\right)$ & $98.553(2)$ \\
\hline$\gamma\left({ }^{\circ}\right)$ & 90 \\
\hline$V\left(\AA^{3}\right)$ & $3315.6(6)$ \\
\hline Molecular weight & 1125.07 \\
\hline Space group & $P 2 / c$ \\
\hline$\mu\left(\mathrm{mm}^{-1}\right)$ & 2.139 \\
\hline Temperature (K) & $296(2)$ \\
\hline$Z$ & 4 \\
\hline$D_{\text {calc }}\left(\mathrm{g} \mathrm{cm}^{-3}\right)$ & 2.254 \\
\hline Crystal size $\left(\mathrm{mm}^{3}\right)$ & $0.13 \times 0.06 \times 0.02$ \\
\hline Radiation & $\mathrm{MoK}_{\alpha}$ \\
\hline Total reflections & 18206 \\
\hline Unique reflections & 5555 \\
\hline Angle range $2 \theta\left({ }^{\circ}\right)$ & $2.93-50.00$ \\
\hline Reflections with $\left|F_{\mathrm{O}}\right| \geq 4 \sigma_{\mathrm{F}}$ & 4698 \\
\hline$R_{\mathrm{int}}$ & 0.0464 \\
\hline$R_{\sigma}$ & 0.0365 \\
\hline$R_{1}\left(\left|F_{\mathrm{o}}\right| \geq 4 \sigma_{\mathrm{F}}\right)$ & 0.0282 \\
\hline $\mathrm{w} R_{2}\left(\left|F_{\mathrm{o}}\right| \geq 4 \sigma_{\mathrm{F}}\right)$ & 0.0691 \\
\hline$R_{1}$ (all data) & 0.0343 \\
\hline $\mathrm{w} R_{2}$ (all data) & 0.0710 \\
\hline$S$ & 1.032 \\
\hline$\rho_{\min }, \rho_{\max }, \mathrm{e} \AA^{-3}$ & $-0.878,1.231$ \\
\hline
\end{tabular}

was applied using the SADABS program. ${ }^{9}$ The unit cell parameters of 1 (Table 1) were determined and refined by the leastsquares techniques on the basis of 18206 reflections with $2 \theta$ in the range $2.93-50.00^{\circ}$. From the systematic absence and statistics of the reflection distribution, the space group $P 2 / c$ was determined. The structure was solved by the direct methods and refined to $R_{1}=0.028\left(\mathrm{w} R_{2}=0.069\right)$ for 4698 reflections with $\left|F_{\mathrm{O}}\right| \geq 4 \sigma_{\mathrm{F}}$ using the SHELXL-97 program incorporated in the OLEX2 program package. ${ }^{10,11}$ The final model included the coordinates and anisotropic displacement parameters for all non-hydrogen atoms. Positions of $\mathrm{H}$ atoms and $\mathrm{OH}$ groups were localized from the difference Fourier maps and kept fixed during refinement with $U_{\text {iso }}(\mathrm{H})=1.2 U_{\text {eq }}(\mathrm{O})$. The main interatomic distances and bond angles are summarized in Tables S1-S3. $\dagger$ The unit cell of $\mathbf{1}$ contains disordered partially occupied dichloromethane molecules that have been treated as a diffuse contribution to the overall scattering without specific atom positions by SQUEEZE/PLATON. ${ }^{12}$ The total approximate number of solvent molecules in the structure of $1 \cdot 0.5 \mathrm{CH}_{2} \mathrm{Cl}_{2}$ has been calculated taking into account the electron count of 88 and the total potential solvent accessible void volume of 312.5 e $\AA^{-3}$. Supplementary crystallographic data for this paper have been deposited at Cambridge Crystallographic Data Centre (CCDC 1463843).

\section{Results and discussion}

We suggested that $\left[\mathrm{TcF}(\mathrm{CO})_{5}\right]$ can be obtained by the heterogeneous reaction of $\left[\mathrm{TcI}(\mathrm{CO})_{5}\right]$ with $\mathrm{AgF}$. We believe that in our case the reaction can be promoted by formation of "strong" silver iodide. Similar synthesis performed by Chaudhuri et al. with $\left[\mathrm{MnBr}(\mathrm{CO})_{5}\right]^{13}$ yielded only the poorly characterized tricarbonyl complex "[ $\left.\mathrm{MnF}_{3}(\mathrm{CO})_{3}\right]$ ". To decelerate decarbonylation of $\left[\mathrm{TcF}(\mathrm{CO})_{5}\right]$, the synthesis was performed at low temperature $\left(-23{ }^{\circ} \mathrm{C}\right)$. The reaction was monitored by IR spectroscopy. Initially we used hexane as the solvent. The reaction mixture was stirred at $-23{ }^{\circ} \mathrm{C}$ for $1 \mathrm{~h}$. Its IR spectrum in the range of stretching vibrations of carbonyl groups was similar to that of technetium pentacarbonyl iodide in hexane [2142.8 (vw), 2054.0 (vs), and $2000.0(\mathrm{~m}), \mathrm{cm}^{-1}$ ]. After heating the reaction mixture to room temperature, no changes in the spectrum were observed either. Thus, $\left[\mathrm{TcI}(\mathrm{CO})_{5}\right]$ does not react with $\mathrm{AgF}$ in hexane. To promote the reaction, we tested dichloromethane, which slightly dissolves silver fluoride. Indeed, the bands of initial $\left[\mathrm{TcI}(\mathrm{CO})_{5}\right]$ at $2148.6(\mathrm{vw}), 2054.0$ (vs) and $2003.9(\mathrm{~m}) \mathrm{cm}^{-1}$ (Fig. S1†) disappeared after stirring solid AgF in a dichloromethane solution of $\left[\mathrm{TcI}(\mathrm{CO})_{5}\right]$ at room temperature. However, in this case the spectrum of the reaction mixture contained two bands typical for tricarbonyl complexes [2050.2 (m) and $\left.1949.9(\mathrm{~s}) \mathrm{cm}^{-1}\right]$. When the reaction was performed at $-23{ }^{\circ} \mathrm{C}$ for $1 \mathrm{~h}$, new bands typical for the pentacarbonyl complexes at $2148.6(\mathrm{vw}), 2069.5(\mathrm{vs})$ and $1996.2(\mathrm{~m}) \mathrm{cm}^{-1}$ appeared (Fig. 1). The band at $1938.3 \mathrm{~cm}^{-1}$ is most likely assigned to a tricarbonyl decarbonylation product formed from the new pentacarbonyl complex $\left(\left[\mathrm{TcI}(\mathrm{CO})_{5}\right]\right.$ is stable with 


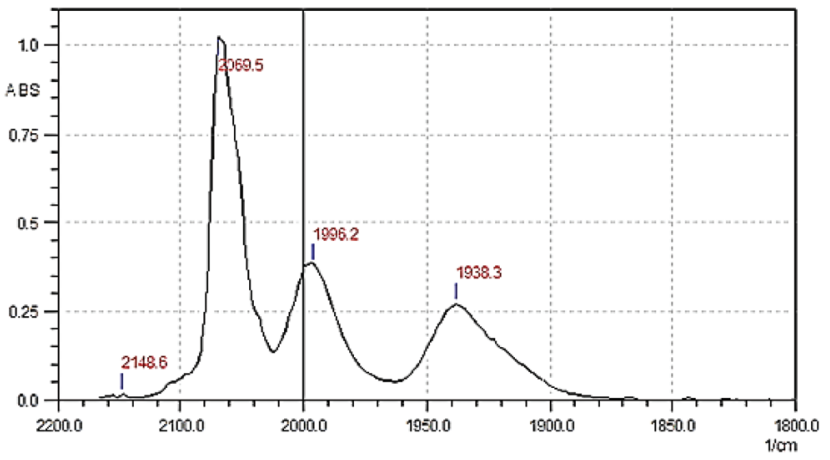

Fig. 1 IR spectrum of a mixture of $\left[\mathrm{Tcl}(\mathrm{CO})_{5}\right]$ and $\mathrm{AgF}$ stirred in $\mathrm{CH}_{2} \mathrm{Cl}_{2}$ for $1 \mathrm{~h}$ at $-23^{\circ} \mathrm{C}$.

respect to thermal decarbonylation under these conditions). ${ }^{6}$ The second band characteristic of tricarbonyl species and expected in the region of $2050 \mathrm{~cm}^{-1}$ probably is not resolved with the band at $2069.5 \mathrm{~cm}^{-1}$.

The sixth coordination site in the pentacarbonyl complex can presumably be occupied by fluoride and chloride anions. Since the most intense carbonyl band of technetium pentacarbonyl chloride in a dichloromethane solution is at $2059.1 \mathrm{~cm}^{-1},{ }^{14}$ formation of this complex by chlorination with the solvent can be ruled out. Thus, the pentacarbonyl complex formed in the reaction mixture is most likely $\left[\mathrm{TcF}(\mathrm{CO})_{5}\right]$. Unfortunately, the complex rapidly (within $1 \mathrm{~h}$ ) decarbonylates in a solution at room temperature to form the tricarbonyl species. The formation of tricarbonyl complexes is confirmed by the appearance of the band at $1938.3 \mathrm{~cm}^{-1}$, growing with time. All attempts to isolate pure $\left[\mathrm{TcF}(\mathrm{CO})_{5}\right]$ and to perform its elemental analysis failed. Crystallization of the pentacarbonyl complex by slow evaporation of its dichloromethane solution in a fridge yielded colorless crystals suitable for single crystal X-ray diffraction. Single crystal X-ray diffraction showed that the crystal structure of $\mathbf{1}$ consists of two types of technetium carbonyl complexes with a hydrogen bridge (Fig. 2).

The first is a distorted cube composed of two interpenetrating tetrahedra $\mathrm{Tc}_{4}$ and $(\mathrm{F}, \mathrm{OH})_{4}$, with the $(\mathrm{F}, \mathrm{OH})-\mathrm{Tc}-(\mathrm{F}, \mathrm{OH})$

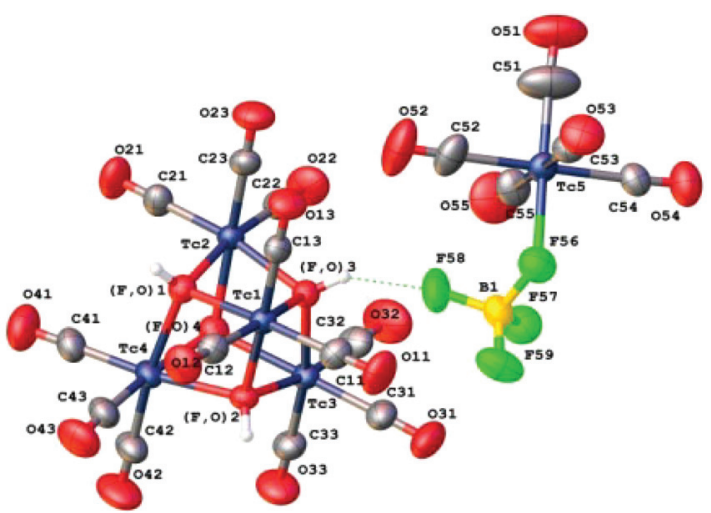

Fig. 2 Molecular structure of 1. angles smaller than the Tc-(F,OH)-Tc angles. This distortion of the octahedral structure is typical for cubic clusters of Group VI-VIII transition metals. ${ }^{15-17}$

Each of the four crystallographically independent technetium atoms of the tetrameric fragment forms three bonds with the carbon atoms of the carbonyl groups. The three remaining bonds correspond to the (F,OH) positions of the cube skeleton, which results in strong distortion of the technetium octahedron. Four crystallographically independent positions of the $(\mathrm{F}, \mathrm{OH})_{4}$ tetrahedron are occupied with fluorine atoms and oxygen atoms of the hydroxy groups.

We attempted to refine the structure assuming that the positions are occupied exclusively by oxygen or fluorine atoms. However, this attempt led to increased values of R-factors, residual oxygen electron density, and thermal displacement parameters of fluorine. In addition, weak peaks of hydrogen atoms of hydroxy groups are clearly observed in the electron density maps. Refinement of the occupancies showed nonuniform distribution of fluorine atoms and hydroxy groups over each site, with approximately similar total occupancy $(\mathrm{F}=2.04$ at. units; $\mathrm{OH}=1.96$ at. units).

The second complex is a slightly distorted octahedron, which is typical for carbonyl complexes of univalent technetium. Technetium forms five bonds with the carbonyl carbon atoms. Four of them are similar in length, $\mathrm{Tc}(5)-\mathrm{CO}=$ 2.002(6)-2.024(5) $\AA$, and the fifth bond trans to the $\mathrm{BF}_{4}$ ligand is shortened, $\mathrm{Tc}(5)-\mathrm{C}(51) \mathrm{O}_{\text {trans }}=1.895(6) \AA$. The sixth coordination site is occupied by the fluorine atom of $\mathrm{BF}_{4}$ with $\mathrm{Tc}(5)-\mathrm{F}(56)=2.178(3) \AA$.

In the crystal structure of $\mathbf{1}$, technetium clusters are bound by hydrogen bonds $\mathrm{Tc}-\mathrm{OH}(1) \cdots \mathrm{F}(57)-\mathrm{B}(1)-\mathrm{F}(58) \cdots \mathrm{H}(3) \mathrm{O}-\mathrm{Tc}$ to form infinite chains in the (010) plane (Fig. 3).

The packing of the chains is similar to the close packing of cylinders in the [010] plane. The chains are bound with each other by intermolecular van der Waals bonds. It should be noted that the $(\mathrm{F}, \mathrm{OH})$ sites involved in the chain formation are mainly occupied by the hydroxy groups $(\mathrm{F}(1)=0.35$ at. units; $\mathrm{F}(3)=0.27$ at. units), whereas the remaining sites are occupied mainly by the fluorine atoms $(F(2)=0.60$ at. units; $F(4)=$ 0.81 at. units).

It is most likely that the $\mathrm{BF}_{4}{ }^{-}$anion is formed by the reaction of fluoride ions with the glass of the vial being used for

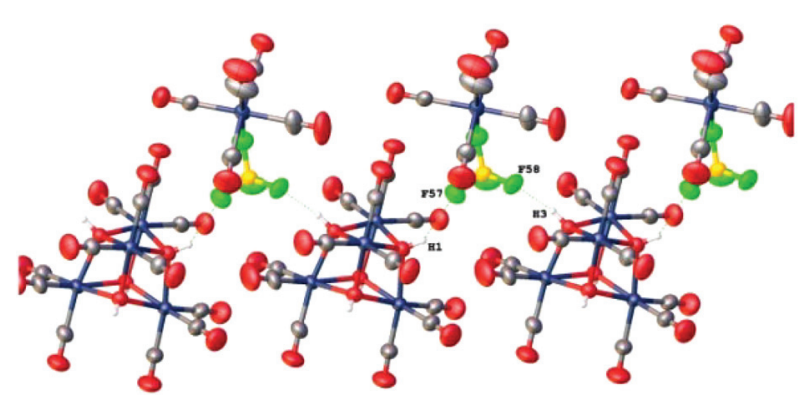

Fig. 3 Crystal structure of 1. 
crystallization. To rule out the formation of $\left[\mathrm{Tc}\left(\mathrm{BF}_{4}\right)(\mathrm{CO})_{5}\right]$ in the course of reaction of $\mathrm{AgF}$ with $\left[\mathrm{TcI}(\mathrm{CO})_{5}\right]$, we performed the reaction of $\left[\mathrm{TcI}(\mathrm{CO})_{5}\right]$ with $\mathrm{AgBF}_{4}$ to obtain $\left[\mathrm{Tc}\left(\mathrm{BF}_{4}\right)(\mathrm{CO})_{5}\right]$. A weighed portion of $\left[\mathrm{TcI}(\mathrm{CO})_{5}\right](28.14 \mathrm{mg}, 0.077 \mathrm{mmol})$ was dissolved in dry dichloromethane $(3 \mathrm{ml})$. The resulting solution was added to a weighed portion of $\mathrm{AgBF}_{4}(27.60 \mathrm{mg}$, $0.14 \mathrm{mmol}$ ) taken in 1.84-fold excess. The reaction mixture was stirred on a magnetic stirrer at room temperature in the dark for $1 \mathrm{~h}$. In the course of stirring a fine yellow precipitate was formed. The precipitate and unchanged $\mathrm{AgBF}_{4}$ were filtered off. The IR spectrum of the product is shown in Fig. 4. As can be seen, the spectrum is consistent with the expected product formula $\left[\mathrm{Tc}\left(\mathrm{BF}_{4}\right)(\mathrm{CO})_{5}\right]$ (detailed characterization of this compound is planned in the future) and differs essentially from that of the product formed in solution in the reaction with $\mathrm{AgF}$ and presumably identified as $\left[\mathrm{TcF}(\mathrm{CO})_{5}\right]$. Another difference is that this product, in contrast to $\left[\mathrm{TcF}(\mathrm{CO})_{5}\right]$, is stable at room temperature at least within the time required for the sample synthesis, separation of the precipitate, and filling of the IR cell (about $2 \mathrm{~h}$ in total). The amount of tetrameric species, which should give a strong band in the region of $1950 \mathrm{~cm}^{-1}$, is negligible.

These facts suggest formation of $\left[\mathrm{TcF}(\mathrm{CO})_{5}\right]$ and its subsequent conversion to $\mathbf{1}$ during low-temperature crystallization. To prevent formation of the tetrafluoroborate anion, the reaction of $\left[\mathrm{TcI}(\mathrm{CO})_{5}\right]$ with $\mathrm{AgF}$ was performed in a plastic vial under conditions similar to those of the reaction in the glass vial. The IR spectrum of the reaction mixture stirred at $-23{ }^{\circ} \mathrm{C}$ for $1 \mathrm{~h}$ was similar to that of the reaction mixture in the glass vial. Our attempts to grow a crystal of technetium carbonyl fluoride complex in a plastic vial failed. It should be noted that atmospheric moisture significantly affects the reaction between $\left[\mathrm{TcI}(\mathrm{CO})_{5}\right]$ with $\mathrm{AgF}$. The IR spectrum of the reaction product obtained after exposure of the reaction mixture to air, followed by crystallization under Ar, was similar to that of $\left[\mathrm{Tc}(\mathrm{OH})(\mathrm{CO})_{3}\right]_{4}$ prepared by us previously ${ }^{18}$ and characterized later in detail by Alberto et al. ${ }^{19}$ Thus, the fluoride anion in the coordination sphere of technetium carbonyl complexes is readily substituted by a hydroxide ion.

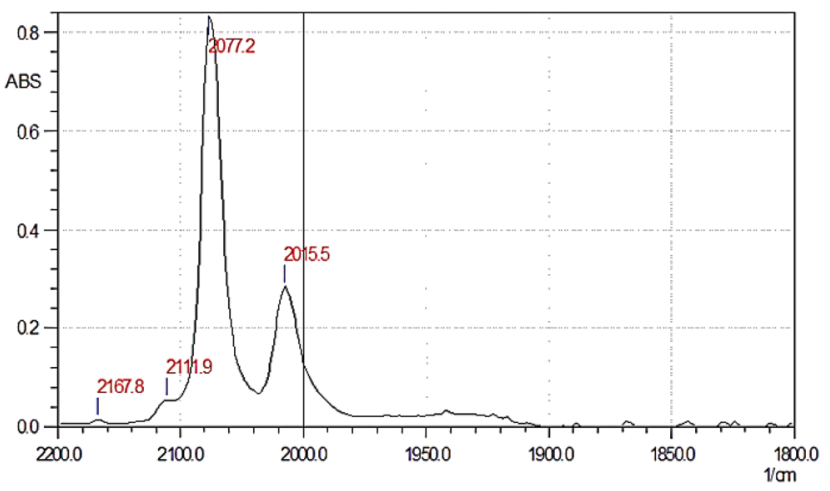

Fig. 4 IR spectrum of the reaction product of $\left[\mathrm{TCl}\left(\mathrm{CO}_{5}\right)\right]$ with $\mathrm{AgBF}_{4}$ in dichloromethane.

\section{Conclusions}

Thus, technetium pentacarbonyl fluoride was prepared for the first time by substitution of the iodide ion in $\left[\mathrm{TcI}(\mathrm{CO})_{5}\right]$ with the fluoride anion in a dichloromethane solution using $\mathrm{Ag}^{+}$as an iodide acceptor. This compound is unstable and rapidly undergoes decarbonylation at room temperature in a dichloromethane solution. Attempted low-temperature crystallization of $\left[\mathrm{TcF}(\mathrm{CO})_{5}\right]$ from a dichloromethane solution in a glass vial yields a mixed tricarbonyl hydroxyfluoride-pentacarbonyl tetrafluoroborate technetium complex characterized by single crystal X-ray diffraction.

\section{Acknowledgements}

XRD study has been performed at the X-ray Diffraction Centre of St Petersburg State University.

\section{Notes and references}

1 T. A. O'Donnell, K. A. Phillips and A. B. Waugh, Inorg. Chem., 1973, 12(6), 1435-1437.

2 D. M. Bruce, A. J. Hewitt, J. H. Holloway, R. D. Peacock and I. L. Wilson, J. Chem. Soc., Dalton Trans., 1976, 2230-2235.

3 N. I. Gorshkov, A. A. Lumpov, A. E. Miroslavov and D. N. Suglobov, Czech. J. Phys., 2003, 53, 745-749.

4 A. E. Miroslavov, N. I. Gorshkov, M. S. Grigor'ev, G. V. Sidorenko and D. N. Suglobov, Radiochemistry, 1997, 39, 40-44.

5 A. E. Miroslavov, A. A. Lumpov, G. V. Sidorenko, E. M. Levitskaya, N. I. Gorshkov, D. N. Suglobov, R. Alberto, H. Braband, V. V. Gurzhiy, S. V. Krivovichev and I. G. Tananaev, J. Organomet. Chem., 2008, 693, 4-10.

6 A. E. Miroslavov, G. V. Sidorenko, A. A. Lumpov, V. A. Mikhalev and D. N. Suglobov, Radiochemistry, 2009, 51, 5-10.

7 G. V. Sidorenko, A. E. Miroslavov, M. S. Grigor'ev, V. V. Gurzhiy, A. A. Lumpov, V. A. Mikhalev and D. N. Suglobov, Radiochemistry, 2011, 53, 44-50.

8 Handbook of preparative inorganic chemistry, ed. G. Brauer, Acad. Press, NY, 1956.

9 G. M. Sheldrick, SADABS, Univ. Göttingen, Germany, 2007.

10 G. M. Sheldrick, Acta Crystallogr., Sect. A: Fundam. Crystallogr., 2008, 64, 112-122.

11 O. V. Dolomanov, L. J. Bourhis, R. J. Gildea, J. A. K. Howard and H. Puschmann, J. Appl. Crystallogr., 2009, 42, 339-341.

12 A. L. Spek, PLATON, A Multipurpose Crystallographic Tool, Utrecht University, Utrecht, The Netherlands, 2005.

13 M. K. Chaudhuri, M. M. Kaschari and D. Winkler, J. Organomet. Chem., 1976, 113, 387-389.

14 A. E. Miroslavov, V. V. Gurziy, M. Yu. Tyupina, A. A. Lumpov, G. V. Sidorenko, Yu. S. Polotskii and D. N. Suglobov, J. Organomet. Chem., 2013, 745-746, 219-225.

15 S. P. Gubin, Cluster Chemistry, Moscow, Nauka, 1987. 
16 N. A. Baturin, M. S. Grigor'ev, S. V. Kryuchkov, A. E. Mirosalvov, G. V. Sidorenko and D. N. Suglobov, Radiokhimiya, 1994, 36, 199-201.

17 M. S. Grigor'ev, A. E. Mirosalvov, G. V. Sidorenko, Yu. T. Struchkov, D. N. Suglobov and A. I. Janowskiy, Radiochemistry, 1995, 37(3), 177-179.
18 A. E. Mirosalvov, G. V. Sidorenko, I. V. Borisova, E. K. Legin, A. A. Lychev and D. N. Suglobov, Radiokhimiya, 1989, 31(6), 33-35.

19 R. Alberto, R. Schibli, A. Egli, U. Abram, S. Abram, T. A. Kaden and P. A. Schubiger, Polyhedron, 1998, 17(7), 1133-1140. 